Mgr Elżbieta Perkowska-Gawlik

UMCS Lublin

e-mail: eperkowskagawlik@gmail.com

\title{
Between Pure Entertainment and Informative Guidance: The Heterotopia of Rehab Institutions in Elizabeth Zelvin's Cozy Mystery Death Will Get You Sober
}

Cozies are detective novels which retain the formula of the classical whodunit flourishing in the 1920's and 1930's. The beginning of the period known as the Golden Age is indicated by the publication of Agatha Christie's first detective novel The Mysterious Affair at Styles. The development and immense popularity of classical mystery novels in the interwar years are often ascribed to the "changes in reading habits"1.

In the wake of the Great War, the previously largely masculine audience for crime fiction had been drastically reduced and predominantly female post-war readership required a different kind of fiction; not short stories in the periodicals purchased on the way to work but longer fiction, in Britain often borrowed from one of the increasing number of public lending libraries ${ }^{2}$.

Worthington suggests that to a large extent the cozy mystery was created in response to the growing demand of female readership, whose social position changed in the process of emancipation ${ }^{3}$. Symons underlines the importance of the phenomenon that a great deal of detective fiction was "written by women, and

1 J. Symons, Bloody Murder: From the Detective Story to the Crime Novel, London: Faber \& Faber 1972, p. 93. p. 116.

2 H. Worthington, Key Concepts in Crime Fiction, Basingstoke: Palgrave Macmillan 2011,

3 Ibidem. 
essentially also for women"4. It appears that women turned to reading the classical whodunit since the idea that they may be engaged in the long process of solving the most complicated criminal conundrums along with the amateur sleuth appeared to be appreciative of the female power of mind. Moreover, the cozy mystery, which neglected the highly problematic economic conditions of the twenties and thirties ${ }^{5}$, presenting the indestructible world of the affluent only temporarily troubled by a 'dead body', provided an escape into "the fairy tale land of the Golden Age"6.

Cozy mysteries like many fairy tales are optimistic in their message: once the perpetrator is exposed and punished the peaceful life of the closed society which happened to be endangered by the crime is momentarily restored. As Canfield Reisman observes "cozy mysteries always conclude on optimistic notes. Thus, they simultaneously provide intelligent readers with intellectual challenges while enabling them to escape from a world in which the news always seems to be troubling"7. Involving its readers in intellectual games, i.e. solving clue puzzles, the classical whodunit of the Golden Age provides pure entertainment which is not meant to strike any emotional chords. The rules of the game are well known both on the part of the author and on the part of the reader.

"Almost since its inception, critics have been denouncing the rise and announcing the demise of the whodunit", neglecting the devotion of the "pure puzzle' readership. For example, in his seminal study Adventure, Mystery, and Romance John G. Cawelti voices some doubts concerning the future of the pattern stating that "historians and critics seem to generally agree that the 'golden age of detection' is past". In Cawelti's view the highly formulaic genre where the order of the presented world is never questioned but always sustained apparently has ceased to provide "a major stimulus to creativity" 10 . The rational reasoning so much favoured by the genre does not correspond with the prevailing irrationality and ambiguity faced by contemporary readers. Moreover, the certainty that the detective is able

4 J. Symons, op. cit., p. 94.

5 In Bloody Murder, Julian Symons notes that detective novels of the interwar period neglect the deep economic depression suffered on both sides of the Atlantic. The characters of these mysteries, unlike their readers, were never troubled by strikes, raging unemployment, or growing popularity of different totalitarian systems.

6 J. Symons, op. cit., p. 104.

7 R.M. Canfield Reisman, Cozies, [in:] Critical Survey of Mystery and Detective Fiction, vol. 1, ed. C. Rollyson, Pasadena, California: Salem Press 2008, p. 2011.

8 G. Grella, Murder and Manners: The Formal Detective Novel, "Novel: A Forum on Fiction" 1970, vol. 4, no. 1, DOI: https://doi.org/10.2307/1345250, p. 30.

9 J.G. Cawelti, Adventure, Mystery, and Romance: Formula Stories as Art and Popular Culture, Chicago: University of Chicago Press 1976, p. 136.

10 Ibidem. 
to protect the social order only momentarily disrupted by the crime "[embodies E. P.-G.] a quaintly antiquated view of the world"11.

Fortunately for the avid readers of cozy/domestic/traditional mysteries, this subgenre of crime fiction, which is typically associated with authors like Agatha Christie or Dorothy Sayers, has not only retained its popularity but also begun to "[expand-E. P.-G.] in directions that were never envisioned by the creators of the genre" ${ }^{\prime 2}$. The cozies of the late twentieth and early twenty-first century are richly encrusted with references to readers' interests, which more often than not means that an amateur sleuth, frequently a woman, with at least college education, apart from solving the criminal conundrum is a specialist in some field. There are myriad occupations of amateur sleuths, such as a librarian, a florist, a gardener, a nun, a teacher, an economist, a nurse, a psychotherapist, or even a bead maker ${ }^{13}$. The extensive and frequently updated lists of contemporary cozy mysteries provided by numerous websites either entirely devoted to this subgenre, such as cozy-mystery. com, or dealing with crime fiction in general where cozies occupy a prominent position, such as stopyourekillingme.com, make it clear that regarding cozies as "a booming business" is not an exaggeration.

The triumphant "revival of cozy [mysteries - E. P.-G.] was officially recognized by the establishment in 1989 of Malice Domestic ${ }^{14}$ [...] for the purpose of paying tribute to the types of traditional mysteries typified by the works of Agatha Christie"15. "Domestic" is next to "traditional", "classical" and "cozy" another name given to works which follow in the footsteps of the mysteries written by the Queen of Crime. "Mysteries which contain no explicit sex, or excessive gore, or violence" 16 is a very succinct but quite an apt definition of novels which are taken into consideration as Agatha Award nominees.

Since the competition is fierce, even having been shortlisted for the awards granted by Malice Domestic appears to be a success. Elizabeth Zelvin takes her place with the group of mystery writers who have been honoured to become an

11 Ibidem.

12 R.M. Canfield Reisman, op. cit., p. 2019.

13 For more occupations, interests and hobbies of amateur detectives as well as the list of relevant cozy mysteries see Cozy Mysteries by Themes, [online]. Available on the internet: https://www.cozy-mystery.com/cozy-mysteries-by-themes.html [accessed: 16 September 2017$].$

14 Malice Domestic is a nonprofit organization established in 1989 which gathers fans of the traditional detective novel typified by Agatha Christie's mysteries. For further information concerning the conferences or other events organised by Malice Domestic visit its website: Malice Domestic. About, [online]. Available on the internet: http://malicedomestic.org/about. html [accessed: 16 September 2017].

15 R.M. Canfield Reisman, op. cit., p. 2017.

16 The website of Malice Domestic: Malice Domestic, [online]. Available on the internet: http://malicedomestic.org/about.html/ [accessed: 16 September 2017]. 
Agatha Award nominee. Two out of her three highly valued short stories belong to the Bruce Kohler mystery series, where Zelvin intertwines criminal intrigues with her professional knowledge and experience derived from working with alcohol and drug addicts.

Being an alcoholic can hardly be regarded as an occupation or a hobby, nevertheless, this is the only way in which an amateur sleuth created by Elizabeth Zelvin defines himself. The decision to join a clue-puzzle with the everyday reality of alcoholics is by no means coincidental since Zelvin before becoming a mystery writer and turning to online counselling and therapy in 2000 was a clinical social worker and psychotherapist for twenty years. A Counsellor Emerita designated by the New York State Office of Alcoholism and Substance Abuse Services, Zelvin has not only worked with addicts and their codependent families, but has also been an author and coordinator of many treatment programs and lectured widely on treating addictions and traumas connected with them ${ }^{17}$. Apart from numerous articles on alcohol and drug abuse published in highly regarded scholarly journals ${ }^{18}$, in 2008 she wrote her first mystery of the Bruce Kohler series entitled Death Will Get You Sober. So far she has published ten mysteries of the series, either in form of a novel or a short story, the most recent in 2015. All Death Will mysteries ${ }^{19}$ feature the recovering alcoholic Bruce Kohler and his two friends, Barbara, a counsellor and a codependent, as well as Jimmy, a computer 'wizard' who is Bruce's best friend and Barbara's partner.

In Death Will Get You Sober Bruce not only starts his adventure with the state of sobriety but also with criminal investigation. He is shocked and simultaneously intrigued by the sudden death of Godfrey - a person he met and liked in detox. He decides to dig deeper and find out whether Godfrey was killed by alcohol or whether somebody murdered him.

Undoubtedly, Zelvin's professional life, which has been closely connected with booze and all its effects, provides her with ample material and ideas for writing mysteries set in the rehab institutions and peopled with characters based on addicts she treated. She presents the world of alcoholics not only from the perspective of a therapist, but also from that of the addict. Only in a few chapters of Death Will Get You Sober, Barbara is the focalizer, whereas in the majority of them Zelvin meets the challenge and adopts the vantage point of Bruce, whose life has been dominated

17 Elizabeth Zelvin's bio and credentials are provided at her website entitled LZcybershrink for Online Therapy, [online]. Available on the internet: http://www.lzcybershrink.com/more.htm [accessed: 10 September 2017].

18 To see the list of Elizabeth Zelvin's professional publications visit her website. Ibidem.

19 For more titles in the Bruce Kohler mystery series visit Elizabeth Zelvin's website devoted to her writing: Elizabeth Zelvin. Bruce Kohler Mysteries, [online]. Available on the internet: https://www.elizabethzelvin.com/Books.htm [accessed: 14 July 2017]. 
by the excessive consumption of alcohol or for some periods the enforced, and hardly ever appreciated, abstention from it.

To familiarise the reader with the structured process of giving assistance to the addicted in order to bring them back to society, Zelvin marginalises domestic spaces, setting most of the action either in a detox institution or at AA meetings. Although such places can be easily found in many cities, they are considered different from all the other spaces. Foucault would regard them as heterotopias i.e. "places [...] outside all places, even though it may be possible to indicate their location in reality" Heterotopias "are something like counter-sites, a kind of effectively enacted utopia in which the real sites, all the other real sites that can be found within the culture, are simultaneously represented, contested and inverted"21. Foucault distinguishes certain features of heterotopias, yet he fails to give a clear-cut definition of the phenomenon, which, paradoxically, has proved to be a great advantage of the concept: its openendedness has encouraged scholars to develop the notion of heterotopia in various directions. In his essay Interpretations of Heterotopia of 2016, Peter Johnson not only outlines different and frequently contradictory readings of Foucault's 'other spaces', but also enumerates "a dazzling variety of spaces [that - E. P.-G.] has been explored as illustrations of heterotopia" ${ }^{22}$, such as pornographic sites on the internet, the public nude beach, the shopping mall, hospitals and many others, which considerably widens the set of examples provided by Foucault. A detox institution expands Foucault's list as it represents a perfect model of a heterotopia of deviation, sharing numerous features with rest homes, psychiatric hospitals and prisons. Moreover, the rehab institution is unquestionably peopled with "individuals whose behaviour is deviant in relation to the required mean or norm"23.

The detox institution in Zelvin's novel, the Bowery, is named after a charity organisation for addicts in New York City. There, one Christmas Day, Bruce Kohler, the protagonist, finds himself in an exceptionally appalling state: "My mouth tasted like a garbage scow, my memory was on lockdown, and I bitterly regretted not being dead by thirty, the way I'd always thought I'd be"24. It appears that such a physical and mental condition constitutes a peculiar pass to the heterotopia of detox.

20 M. Foucault, Of Other Spaces, transl. by J. Miskowiec, “Diacritics” 1986, vol. 16, no. 1, DOI; https://doi.org/10.2307/464648, p. 24.

21 Ibidem.

22 P. Johnson, Interpretations of Heterotopia, [online]. Available on the internet: http:// www.heterotopiastudies.com/wp-content/uploads/2012/05/Interpretations-of-Heterotopia-pdf. pdf [accessed: 14 July 2017].

23 M. Foucault, op. cit., p. 25.

24 E. Zelvin, Death Will Get You Sober, New York: Thomas Dunne Books/St. Martin's Minotaur 2008, p. 3. 
Heterotopias always presuppose a system of opening and closing that both isolates them and makes them penetrable. In general, the heterotopic site is not freely accessible like a public space. Either the entry is compulsory, as in the case of entering [...] prison, or else the individual has to submit to rites and purifications. To get in one must have a certain permission and make certain gestures ${ }^{25}$.

People who are brought into the Bowery are invariably intoxicated, hence barely conscious, and as far as "certain gestures" are concerned they simply keep vomiting. From now on they must not drink, yet they still feel the effect of booze, it is present in their thoughts, talks and dreams. The stories about their intoxicated past create a curious understanding, one may even say a special bond between them.

By evening, Godfrey's guts were behaving little better $[\ldots]$ we exchanged some basic information. Preferred brand of gin - Tanqueray. Favourite Scotch - Chivas Regal, both of us [...]. What bars we drank in. [...] Compared notes on what the hell we were doing in a place like this. He couldn't remember, either. Kindred spirits ${ }^{26}$.

The alcoholics' bond established on such wobbly foundations is sustained and strengthened by the daily routine of the Bowery. They are obliged to conform to all the regulations of the detox, even humiliating ones, since inmates who violate the rules are expelled immediately. The paradox is that the Bowery bears a strong resemblance to prisons with one essential difference: despite feeling incarcerated there, alcoholics do not want to escape.

After we'd been good for a few days, they might let us out on pass. But they would breathalyze us and check our urine for drugs when we got back. No asking a buddy outside to lend you a little jar of clean piss, either. One of the counsellors would watch you perform ${ }^{27}$.

Both Godfrey and Bruce manage to return from the pass clean; however, during the night Godfrey gets terrible cramps, as if he was poisoned, and dies in agony. Alcoholics are said to be deprived of any feelings, interests and goals, yet Bruce cannot come to grips with Godfrey's death partly because he witnessed it but also because Godfrey's health compared to that of the other residents' of the Bowery was surprisingly good.

However, the Bowery staff are not interested in investigating any deaths that happen on the premises. Barbara, who is a counsellor, dispels any illusions con-

${ }_{25}$ M. Foucault, op. cit., p. 26.

${ }^{26}$ E. Zelvin, op. cit., p. 5.

27 Ibidem, p. 20. 
cerning an investigation carried out by the professionals responsible: "everybody expects alcoholics on the Bowery to die. No one will go looking for evidence of murder, and if they did, they wouldn't run around like Lord Peter Wimsey, hunting down appropriate suspects" ${ }^{\prime 2}$. Thus, the Bowery makes a perfect place for planning a perfect murder. The well known joke that sleeping pills swallowed by patients allow the nurse on duty to sleep through the night particularly applies to the Bowery. All the residents are given some sort of tranquilisers which, on the one hand, help them to survive horrific alcohol-free nights but, on the other hand, make them vulnerable and defenceless.

Furtively browsing the patients' files, Barbara learns that Godfrey's death was not the only case when homicide should have been suspected. Since recent documents containing vital information about the deceased have been misfiled and not destroyed, Barbara draws the conclusion that the circle of suspects must be limited to the staff of the Bowery: "The more experienced the professional, the more ingrained the principle: Never, never, never throw out a piece of official paper" ${ }^{29}$.The small number of suspects conforms to the formula of the detective story which has its roots in Edgar Allan Poe's ratiocinative tales; especially two of them, namely The Murders in the Rue Morgue and The Purloined Letter are regarded as "the twin fountainheads of modern crime fiction" ${ }^{30}$. However, all the red herrings that move the investigation out of the Bowery are barely convincing and their main function is to draw a more complete psychological portrait of the victim. What Bruce, Barbara and Jimmy have learn about Godfrey's family relations as well as his sexual inclinations does not present him in a favourable light: Godfrey has been excluded from his family not because of his addiction to alcohol but because of his attempts to molest one of his nephews. This revelation conforms to another crucial rule of the classical detective formula: "The crime must be a major one with the potential for complex ramifications, but the victim cannot really be mourned or the possible complexities of the situation allowed to draw our attention away from the detective and his investigation" ${ }^{31}$. Neither the amateur detectives nor the readers have come to know the victim well enough to mourn him deeply. Godfrey's paedophilic disorder further reduces their empathy and contributes to redirecting their interest to the investigation as such, i.e. the solution of the mysterious deaths of alcoholics in the Bowery.

On account of their status as recovering alcoholics and codependents the three amateur detectives possess a special affinity to the heterotopia of alcoholics, which qualifies them to examine the enigmatic cases in 'the other space'. In classical

\footnotetext{
28 Ibidem, p. 62.

29 Ibidem, p. 227.

30 C. Rzepka, Detective Fiction, Cambridge: Polity Press 2005, p. 74.

31 J.G. Cawelti, op. cit., p. 81.
} 
detective novels amateur sleuths are ready-made constructs whose features or skills qualify them as investigators and define their role in the narrative progression. They are not expected to develop or perfect their investigative methods but to apply them efficiently to untangle yet another allegedly insoluble criminal conundrum. The reader follows their reasoning, learns from them, even competes with them, trying either to anticipate their next move or simply guess the solution earlier, yet, primarily, he or she is supposed to admire them. After all, what readers of Poe's or Doyle's stories remember best are the brilliant and eccentric sleuths Dupin and Holmes. In Death Will Get You Sober, Zelvin's construct of the amateur detective differs considerably: the reader encounters a team of investigators who may be dubbed the three musketeers. Jimmy, Barbara and Bruce are independent entities, playing different yet complementary roles in the course of their investigation. However, their close cooperation while solving the criminal puzzle appears to enhance the complex process of recovery from addiction.

Barbara deeply believes that she and Jimmy must help Bruce to discover the cause of Godfrey's death. Their common enterprise is supposed to be a kind of alternative therapy, keeping Bruce occupied and reducing his feeling of boredom which most alcoholics suffer during the mundane yet demanding process of recovery. Justifying the necessity of combining the struggle to stay sober with the murder investigation Barbara explains:

Don't drink, go to meetings, and investigate a murder. [...] The best reason you might actually make it (stay sober) this time is that you have real feelings about this. You cared about Godfrey, and it hurt you when he died. [...] If finding out why [he - E. P.-G.] died keeps [you E. P.-G.] interested in staying sober, we have no choice ${ }^{32}$.

Zelvin' triple figure of the amateur sleuth epitomises a highly complicated net of interrelations, forming the inseparable domains of the heterotopia of alcoholism. Bruce's love-hate relationship with booze has defined him as a person for many years. The scenario of life which primarily consists of inventing reasons or excuses for drinking is frequently accompanied by the fear of seeing reality undistorted by booze.

Tonight, I had reviewed my whole life. I couldn't do that when I drank, and I didn't enjoy it now. It made me feel bleak. For a guy my age with the brains I'd like to think I have, I hadn't accomplished much. Nor was I eager to change. I'd rather scream and bang my head against the wall. I could think of nothing but that caressing slither of liquid fire running down my throat and my esophagus. What a dumb thing to be enslaved to! Fermented grain. I ask you! ${ }^{33}$

${ }^{32}$ E. Zelvin, op. cit., pp. 61-62.

33 Ibidem, p. 104. 
His only partly conscious decision to stop drinking does not make his situation any easier: "the boredom of sobriety" ${ }^{34}$ as well as the overwhelming loneliness hinder Bruce's ability to survive, not to speak of enjoying life.

Jimmy, whose alliance with booze terminated much earlier, is a great believer in the salutary effect of frequent visits to AA meetings. Participation in such meetings is mandatory during the stay in the Bowery. However, as the attendance at such gatherings must be voluntary this enforcement runs counter to the spirit of AA. In Death Will Get You Sober, the readers, together with Bruce, become acquainted with the Twelve Steps Program of AA, the first point of which is "We admitted we were powerless over alcohol - that our lives had become unmanageable" ${ }^{35}$. Those who are lucky enough and have never entered the infernal world of alcoholics or codependents learn some idiosyncrasies of its language. 'To qualify' is synonymous with being sober for at least ninety days and only then you are entitled 'to share', which means "to tell your story at a meeting"36. A 'Sponsor' is somebody who provides moral support, not someone who gives you money. He or she works with you individually, discussing the Steps as well as AA meetings you attend. Sponsors are also AA members, however more advanced in the process of sobriety. Instead of boring the reader with a plethora of AA rules, traditions and slogans such as "Progress, not perfection" ${ }^{37}$ Zelvin makes this necessary information more palatable by allowing it to enter the dialogues of amiable characters with a great sense of humour. Thus, for example, the reader learns two versions of the Serenity Prayer recited by AA members: the original one, "God grant me the serenity... to accept the things I cannot change... courage to change the things I can ... and the wisdom to know the difference" ${ }^{38}$, as well as the shorter and definitely less elaborate version, which is simply "Fuck it" 39 .

Barbara, the third musketeer, works as a counsellor in an outpatient unit, yet she completed her internship in the Bowery, thus she knows this and similar units in New York from the inside. Not only does she have contacts in all institutions working with addicts but is also the mastermind behind the investigation. Barbara bosses Jimmy and Bruce around and neither of them refuses to cooperate and obey her orders. However, behind the mask of a strong and well-organised young woman, the reader discovers a fragile girl who is trying to prove to herself as well as to the ghost of her domineering mother that she can tackle any problem on her own.

${ }^{34}$ Ibidem.

35 The Twelve Steps of Alcoholics Anonymous, [online]. Available on the internet: http:// www.alcoholics-anonymous.org.uk/About-AA/The-12-Steps-of-AA/ [accessed: 14 July 2017].

36 E. Zelvin, op. cit., p. 81.

37 Ibidem, p. 66.

38 Ibidem, p. 14.

39 Ibidem, p. 23. 
Moreover, Barbara is the voice of reason in the novel: although devoted to her work, she glorifies neither the recovery program nor people working for the institutions. Barbara, it can be argued, is Elizabeth Zelvin's alter ego since both believe in the beneficial aspects of carrying out an investigation. On the intratextual level, Bruce's involvement in solving the criminal conundrum is meant to divert his thoughts from alcohol, whereas on the extratextual level, mystery novels saturated with booze, i.e. with numerous data concerning alcoholism, appear to serve a didactic purpose.

In one of the interviews, asked about her motivation to write mysteries Elizabeth Zelvin gives the following answer:

I certainly write to entertain. I want my books to make readers laugh and cry. I confess I think my writing is hilarious at times. But I also have something to say about recovery — from alcoholism and other addictions, codependency, and eating disorders. It means a lot to me when readers who know nothing about addictions tell me that I've given them a glimpse what it's like, that they've developed some compassion for the suffering and struggle; when readers who have seen people they love self-destruct and know very little about recovery tell me my work gives them hope; and when people in recovery say that what I've written rings true, that it's authentic ${ }^{40}$.

In Zelvin's mystery Death Will Get You Sober the heterotopias of addictions do not only play the role of setting, whose features perfectly suit the classical detective formula but they characterise and, more importantly, shape their 'inhabitants' as well as their mutual relations. Although Zelvin convincingly shows that one does not need to become an addict in order to come within the orbit of alcoholism, her narrative is far from preaching. Instead of exaggerating fear of the disease or a bumpy road to recovery, she cleverly interweaves a plethora of invaluable information concerning the rehab institutions into a gripping criminal intrigue. Thanks to her highly informative narrative the places which are often regarded as either evil or at best surrounded by a veil of mystery are given a different status: their existence appears to be indispensible since, like other heterotopias, they reflect and thus complement the picture of our civilisation.

${ }^{40}$ E. Zelvin, Interview With Mystery Author Elizabeth Zelvin, interview by S. Murphy, L. Lewis Ham, "Kings River Life Magazine", [online], 12 May 2012. Available on the internet: http://kingsriverlife.com/05/12/interview-with-mystery-author-elizabeth-zelvinreviewgiveaway/ [accessed: 10 September 2017]. 


\section{Streszczenie}

\section{Pomiędzy czytadłem a poradnikiem: heterotopia ośrodków terapii uzależnień w powieści detektywistycznej Elizabeth Zelvin Death Will Get You Sober}

Celem artykułu jest ukazanie jednego z kierunków rozwoju tradycyjnej powieści detektywistycznej. Zarówno amatorzy, jak i specjaliści z zakresu różnych dziedzin starają się zaadaptować formułę klasycznego kryminału dla propagowania swojej wiedzy. Rezultatem takich poczynań są powieści, które oprócz wciągnięcia czytelnika w fascynujący proces rozwiązywania zagadki kryminalnej, prezentują zagadnienia związane z pracą bądź zainteresowaniami autora.

Półki księgarskie pełne są poradników przedstawiających metody pokonywania różnorakich problemów trapiących współczesne społeczeństwo, jednakże trafiają one do wąskiego grona odbiorców zainteresowanych konkretnym zagadnieniem. Doceniając ogromną popularność kryminałów, Elizabeth Zelvin, znana i ceniona specjalistka w dziedzinie terapii uzależnień, postanawia użyć formuły klasycznej powieści detektywistycznej w celu przybliżenia szerszemu gronu czytelników zasad pracy z osobami cierpiącymi na chorobę alkoholową. Szczegółowa prezentacja heterotopii ('innych przestrzeni’), do których wstęp mają jedynie chorzy, współuzależnieni i terapeuci, zgrabnie wpleciona w intrygę kryminalną, czyni Death Will Get You Sober spektakularnym przykładem hybrydyzacji konwencji tradycyjnego kryminału.

Słowa kluczowe: kryminał; odwyk; heterotopia; alkoholizm; poradnik

\section{Summary}

The aim of this paper is to discuss the generic direction into which the cozy mystery has been developing. Professionals and amateurs of different domains have started to adopt the medium of the traditional detective novel to propagate their expertise. Consequently, in addition to the criminal clue puzzle these 'hybrid' crime novels provide useful knowledge or even guidance.

Psychotherapists and psychiatrists are among people professionally involved in the wide spectrum of problems haunting addicts and their codependent families. Although there are more and more self-help books on various addictions available on the market, their readership is limited to the unlucky ones who, in one way or another, have been drawn into the "Maelstrom"of alcoholism. Very few non-addicts can comprehend the closed world of alcoholics with all its peculiarities and irregularities. Elizabeth Zelvin, an experienced counsellor, has managed to present the heterotopia of alcoholics to a wider audience. Her cozy mystery Death Will Get You Sober intertwines the criminal investigation with the mundane lives of alcoholics struggling to adjust to the rules and regulations enforced in the detox institutions.

Keywords: cozy; rehab; heterotopia; alcoholism; self-help book 


\section{Bibliography}

Canfield Reisman R.M., Cozies, [in:] Critical Survey of Mystery and Detective Fiction, vol. 1, ed. C. Rollyson, Pasadena, California: Salem Press 2008, pp. 2011-2020.

Cawelti J.G., Adventure, Mystery, and Romance: Formula Stories as Art and Popular Culture, Chicago: University of Chicago Press 1976.

Cozy Mysteries by Themes, [online]. Available on the internet: https:/www.cozy-mystery. com/cozy-mysteries-by-themes.html [accessed: 16 September 2017].

Elizabeth Zelvin. Bruce Kohler Mysteries, [online]. Available on the internet: https://www. elizabethzelvin.com/Books.htm [accessed: 14 July 2017].

Foucault M., Of Other Spaces, transl. by J. Miskowiec, “Diacritics” 1986, vol. 16, no. 1, DOI: https://doi.org/10.2307/464648, pp. 22-27.

Grella G., Murder and Manners: The Formal Detective Novel, "Novel: A Forum on Fiction" 1970, vol. 4, no. 1, DOI: https://doi.org/10.2307/1345250, pp. 30-48.

Johnson P., Interpretations of Heterotopia, [online]. Available on the internet: http://www. heterotopiastudies.com/wp-content/uploads/2012/05/Interpretations-of-Heterotopia-pdf.pdf/ [accessed: 14 July 2017].

LZcybershrink For Online Therapy, [online]. Available on the internet: http://www.lzcybershrink.com/more.htm/ [accessed: 10 September 2017].

Malice Domestic, [online]. Available on the internet: http://malicedomestic.org/about.html/ [accessed: 16 September 2017].

Malice Domestic. About, [online]. Available on the internet: http://malicedomestic.org/ about.html [accessed: 16 September 2017].

Rzepka C., Detective Fiction, Cambridge: Polity Press 2005.

Symons J., Bloody Murder: From the Detective Story to the Crime Novel, London: Faber \& Faber 1972.

The Twelve Steps of Alcoholics Anonymous, [online]. Available on the internet: http://www. alcoholics-anonymous.org.uk/About-AA/The-12-Steps-of-AA/ [accessed: 14 July 2017].

Worthington H., Key Concepts in Crime Fiction, Basingstoke: Palgrave Macmillan 2011.

Zelvin E., Death Will Get You Sober, New York: Thomas Dunne Books/St. Martin's Minotaur 2008.

Zelvin E., Interview With Mystery Author Elizabeth Zelvin, interview by S. Murphy, L. Lewis Ham, "Kings River Life Magazine", [online], 12 May 2012. Available on the internet: http://kingsriverlife.com/05/12/interview-with-mystery-author-elizabethzelvinreviewgiveaway/ [accessed: 10 September 2017]. 